\title{
Kritik Al-Ghazali Terhadap Aliran Bathiniyah Terkait Konflik Politik Sunni dan Syiah di Panggung Sejarah
}

Syamsul Yakin

UIN Syarif Hidayatullah Jakarta

syamsul.yakin@uinjkt.ac.id

Abstrak: Respons aliran Bathiniyah terhadap kritik al-Ghazali bersumber dari karya polemik al-Ghazali, yaitu Fadhäih al-Bäthiniyyah wa Fadhäil alMustazhiriyyah. Karya al-Ghazali ini mendapat respons secara historis-kritis dari kalangan pendukung aliran Bathiniyah atau Syiah Ismailiyah, simpatisan, maupun para ilmuan. Terkait dengan penamaan Bathiniyah, misalnya, al-Ghazali dipandang kurang memahami konteks sosio-historis pada masanya. Karena jika yang dimaksud al-Ghazali adalah al-Bathiniyah, maka itu berarti bukan Ismailiyah. Alasannya, pada saat al-Ghazali menulis karya polemiknya, Ismailiyah di Iran di kenal dengan istilah al-Da'wah al-Hadiyah. Artikel ini selain menyajikan kritik al-Ghazali juga memberikan gambaran tentang respons balik aliran Bathiniyah. Karya al-Ghazali menuai kritik karena ditulis untuk merespons permintaan Khalifah Abbasiyah yang masih muda usia, yakni al-Mustazhir. Dia meminta al-Ghazali untuk mengarang sebuah buku dengan menggunakan dasar kekeliruan Syiah Ismailiyah atau aliran Bathiniyah. Bagi al-Ghazali, kampanye secara literar ini dilakukannya juga untuk membela kesultanan Saljuk yang Sunni yang terancan oleh aliran yang dibawa oleh Hasan al-Sabah tersebut. Tampaknya al-Ghazali ingin mengkompromikan Abbasiyah dan Saljuk yang keduanya Sunni untuk bersama-sama melawan aliran Bathiniyah yang Syiah.

\section{Kata kunci: Sunni, Syiah, al-Ghazali, Aliran Bathiniyyah}

\section{Pendahuluan}

Abu Hamid ${ }^{1}$ al-Ghazali ${ }^{2}$ dilahirkan pada pertengahan abad kelima Hijriyah, di desa Thus kota Khurasan, sekitar masa pengangkatan Sultan Alp Arsalan ke atas singgasana Saljuk. ${ }^{3}$ Di Thus, ${ }^{4}$ al-Ghazali belajar sejumlah ilmu pengetahuan. Setelah itu, ia pergi ke Jurjan, lalu ke Naisabur, ${ }^{5}$ pada saat Imam al-Haramain al-Juwaini wafat pada 478/1085. ${ }^{6}$

Selama tinggal di Baghdad, ${ }^{7}$ ia meniti karir akademiknya hingga mencapai kesuksesan, dan mengantarkannya menjadi tokoh terkenal di seluruh Irak. Yang menarik, al-Ghazali sempat mengajar beberapa pemuka mazhab Hanbali seperti 
Ibn 'Aqil ${ }^{8}$ dan Abu al-Khattab, padahal permusuhan antar mazhab begitu meruncing saat itu. ${ }^{9}$ Dalam waktu yang sama, secara otodidak, al-Ghazali mempelajari filsafat dan menulis buku. Dalam tempo kurang dari dua tahun, ia sudah mengusai filsafat Yunani, terutama yang sudah diolah oleh para filosof muslim sebelumnya.

Namun, pada $1095 \mathrm{M}$ al-Ghazali menderita penyakit jiwa yang membuat dirinya secara fisik tak dapat lagi memberi kuliah. ${ }^{10}$ Kemudian ia meninggalkan Baghdad untuk meninggalkan kehidupan umum. Keadaan yang demikian ini berlangsung selama sepuluh tahun. Selama masa itu al-Ghazali antara lain pergi ke Damaskus, al-Quds, Makkah, dan Madinah. Setelah kehidupan menyendiri ia lalui, pada $499 \mathrm{H}$, Fakhr al-Muluk, putra Nizam al-Muluk, dan Wazir Sanjar, penguasa Saljuk Khurasan, ${ }^{11}$ menekan al-Ghazali untuk kembali ke kerja akademik. Pada bulan Dzulqa'dah/Juli-Agustus 1106 M, alGhazali mulai mengajar di Nizamiyah di Naisabur, ${ }^{12}$ dan tak lama sesudah itu ia menulis karya autobiografis Al-Munqidz min al-Dhalal. ${ }^{13}$ Namun, sebelum meninggalnya, alGhazali kembali berhenti mengajar dan kembali ke Thus. ${ }^{14} \mathrm{Di}$ Thus ia membangun madrasah di samping rumahnya. ${ }^{15}$

Kehidupan al-Ghazali sangat erat kaitannya dengan perkembangan politik Islam dalam pergolakan Dinasti Abbasiyah, yang secara de facto pemerintahannya dikendalikan oleh para sultan Bani Saljuk. Bani Saljuk adalah keturunan Turki yang beraliran Sunni, yang memperlihatkan pengaruh dan berperan besar terutama dalam kancah politik di Baghdad mulai tahun 1308 M. ${ }^{16}$ yaitu ketika berhasil mengambil alih kekuasaan dari Bani Buwaihi di Baghdad. ${ }^{17}$

Kondisi politik Dinasti Abbasiyah, ketika masa hidup al-Ghazali, adalah dinasti yang tidak stabil. Posisi Khalifah hanya menduduki posisi "legitimasi dan menara gading" sebagai pemimpin agama, atau sematamata teratas pada bidang spiritual saja sedang dalam pelaksanaan kekuasaan pemerintahan dipegang oleh mereka yang bergelar sultan, amir, atau raja. ${ }^{18} \mathrm{Di}$ antara khalifah yang memerintah adalah Abu Abdullah Abu Ja'far al-Qaim bi Amrillah (1075 M), Abul Qasim bil Muhtadi bi Amrillah (1075 M), Ahmad Abu Abbas alMustazhir Billah (1094-1118). Sedangkan para sultan Bani Saljuk adalah: Tugril Beg (1055 M), Alp Arsalan (1063 M), Maliksyah (1072 M), Mahmud (1092 M), Barkiyaruk (1094), dan Maliksyah II (1117 M). Tugril Beg adalah sultan yang berhasil mengembalikan otoritas kekhalifahan Abbasiyah di Baghdad dalam upaya kudeta yang dilakukan oleh alBusyairi dari pendukung Syi' ah. ${ }^{19}$ Kemenangan Tugril Beg yang Sunni secara otomatis, telah membuka jalan bagi kekuasaan Islam madzhab Sunni di Baghdad. ${ }^{20}$ 
Dengan gambaran demikian, terlihat bahwa pertama, situasi dan kondisi sosial-politik yang mengitari kehidupan al-Ghazali adalah situasi lingkungan sosial-politik yang sedang berada dalam krisis legitimasi kekuasaan pada satu sisi dan terbelahnya kehidupan sosialekonomi ke dalam fragmentasi etnisitas dan paham keagamaan pada sisi lain. Kedua, secara khusus lingkungan yang mengitari kehidupan al-Ghazali adalah lingkungan Islam yang bermadzhab Sunni dalam bingkai pemerintahan kesultanan Saljuk dan kekhalifahan Abbasiyah yang bermadzhab Sunni pula. ${ }^{21}$

Dari potret sosio-historis-politis seperti itu, maka kemudian tulisan ini akan mengarah pada kritik al-Ghazali terhadap aliran Bathiniyah, yakni melalui karyanya Fadhāih al-Bāthiniyyah wa Fadhāil alMustazhiriyyah yang ditulis untuk khalifah muda usia Bani Abbasiyah, yakni al-Mustazhir.

Al-Mustazhir dilahirkan pada bulan syawal tahun $420 \mathrm{H} .{ }^{22}$ Dia dilantik sebagai khalifah pada saat kematian ayahnya, ${ }^{23}$ tepatnya pada $487 \mathrm{H} / 1094$ M. ${ }^{24}$ sebagai khalifah Abbasiyah ke-28. ${ }^{25}$ Pada saat itu dia baru berusia enam belas tahun dua bulan. ${ }^{26}$ Turut hadir untuk memberikan justifikasi dirinya sebagai khalifah Abbasiyah pada saat itu adalah al-Ghazali, ${ }^{27}$ al-Syasyi, Ibn 'Aqil. ${ }^{28}$ Selain mereka hadir juga Malik ibn Nizam al-Muluk, seorang wazir Sultan Barkiyaruk, para pejabat pengadilan, dan para pembesar Saljuk lainnya. ${ }^{29}$ Dalam catatan Ibn Katsir, ${ }^{30}$ Sultan Barkiyaruk sendiri tidak hadir dalam momentum yang sangat penting tersebut. Penyebabnya, karena Barkiyaruk sedang direpotkan dengan perselisihan melawan Tutush Taj al-Muluk, ${ }^{31}$ pamannya sendiri. ${ }^{32}$

Para ahli sejarah menggambarkan kepribadian al-Mustazhir sebagai sosok yang menawan, baik secara fisik maupun psikis. Menurut Jalaludin al-Suyuthi, al-Mustazhir memiliki perilaku yang lembut, berakhlak mulia dan berlaku baik kepada semua orang. Selain itu, ia juga seorang yang gemar beribadah, memiliki keluasan ilmu, dan bersikap terbuka, toleran, dan dermawan. ${ }^{33}$ Namun secara politis, masa kepemimpinan al-Mustazhir menggambarkan hancurnya institusi kekhalifahan $^{34}$ dan berbagai guncangan yang terus terjadi silihberganti. ${ }^{35}$ Masa pemerintahannya yang relatif panjang, yakni selama hampir 25 tahun $(487 \mathrm{H}$ $512 \mathrm{H} / 1094 \mathrm{M}-1118 \mathrm{M}){ }^{36}$ ditandai dengan berbagai peristiwa politik: (1) lemahnya kekuasaan Abbasiyah sehingga pelaksanaan kekuasaan sepenuhnya ada di tangan Sultan Saljuk; (2) kematian Sultan Maliksyah dan Nizam alMuluk yang dilakukan oleh kelompok Assassin ${ }^{37}$ atau Hasyasyin atau golongan Bathiniyah telah menjadikan tantangan tersendiri; (3) terjadinya perebutan kekuasaan di dalangan lingkungan keluarga Saljuk; dan (5) ancaman eksternal, yakni dengan kedatangan Angkatan Perang Salib. ${ }^{38}$ 
Menurut Abd al-Rahman Badawi, aksi kelompok Assassin atau Hasyasyin atau golongan Bathiniyah cukup meresahkan pemerintahan dengan banyaknya korban yang jatuh dari kalangan pemimpin negara maupun pemimpin agama. ${ }^{39}$ Selain Maliksyah dan Nizam al-Muluk, korban lainnya adalah: Ubaidillah bin Ali al-Khutaibi, seorang Ketua Mahkamah Tinggi di Isfahan, Abu al-'Alla Sha'id bin Muhammad al-Bukhari, seorang Mufti di Isfahan, ${ }^{40}$ al-Ruyani, seorang ahli Ilmu Nahwu, ${ }^{41}$ dan tokoh-tokoh lainnya. Usaha penguasa Saljuk untuk menumpas gerakan ini dengan melancarkan sejumlah serangan ke pusat gerakannya di Alamut selalu gagal. Bahkan pada $490 \mathrm{H}$ gerakan Bathiniyah berhasil menguasai sebelas benteng di seluruh Iran, yang terbentang dari Qahistan di Timur sampai Dailam di Barat Laut. ${ }^{42}$

\section{Kritik al-Ghazali Terhadap Aliran Bathiniyah}

Al-Ghazali dikenal sebagai tokoh anti-Ismailiyah (Bathiniyah) yang melakukan kampanye secara literar. Ia memerangi aliran yang dibawa oleh Hasan al-Sabah melawan kesultanan Saljuk dalam karya Fadhāih alBāthiniyyah..$^{43}$ Dalam sejarah, Nizam al-Muluk dalam karyanya Siyasat Nama, juga ikut mengkritik aliran Bathniyah. Ia sendiri akhirnya dibunuh oleh seorang anggota aliran Bathiniyah atau kaum "Assasin" pada 1092 M. Menurut Farid Jabre, ${ }^{44}$ pasca kematian Nizam al-Muluk, hampir semua pemikiran al-Ghazali tertuju pada polemik anti aliran Bathiniyah. Bagi Massimo Campanini, ${ }^{45}$ hal ini bisa diterima karena al-Ghazali memandang aliran Bathiniyah sebagai bahaya nyata bagi Islam ortodoks, baik secara politis maupun dogmatis. Karena itu, ia mencurahkan banyak karyanya untuk membantah aliran ini, di antara yang paling penting dan akan dibahas secara khusus adalah Fadhāih al-Bāthiniyyah..

Sejak lama karya al-Ghazali ini diterima sebagai tulisan al-Ghazali yang otentik. Isinya telah diuraikan dan dikaji oleh Goldziher pada awal tahun 1916. Kitab ini yang biasa disingkat al-Mustazhiry ditulis untuk merespons permintaan Khalifah Abbasiyah yang masih muda, al-Mustazhir. Dia meminta al-Ghazali untuk mengarang sebuah buku dengan menggunakan dasar kekeliruan Syiah Ismailiyah. Berdasarkan sejumlah informasi dari karya biografisnya, yakni al-Munqīdh min al-Dhalāl (terutama bagian terakhir) alGhazali mempelajari tulisan tentang Ismailiyah (Ta'limiyyah) dalam upaya untuk menyangkal pendapat mereka yang menimbulkan polemik. ${ }^{46}$

Fadhāih al-Bathiniyyah wa Fadhāil al-Mustazhiriyyah dikarang pada periode singkat antara berkuasanya al-Mustazhir (18 Muharram 487/7 Pebruari 1094) dan kepergian al-Ghazali dari Baghdad ketika al-Ghazali mengalami krisis spiritual (Dzulqaidah 488/Nopember 1095). Terdapat perbedaan 
pendapat apakah al-Ghazali menulis Kitab Mustazhiry sebelum atau sesudah wafatnya Khalifah Fatimiyah alMustansir (18 Dzulhijjah 487/29 Desember 1094). Hal ini penting, karena Kitab Mustazhiry dimungkinkan terbit mulai tahun 488 (11 Januari-30 Desember 1095). ${ }^{47}$

Sebenarnya, al-Ghazali mengkritik orang-orang Bathiniyah dalam beberapa buku. Yang pertama dia tulis adalah al-Mustazhiry atas permintaan khalifah alMustazhir. Diikuti dengan Hujjat al-Haq (pembuktian kebenaran) yang ditulis sebagai tanggapan langsung untuk argumen orang-orang Bathiniyah yang dijumpai di Baghdad. Setelah meninggalkan posisinya di Nizamiyah, dia menulis Mufassil al-Khilaf (menjelaskan pertentangan) yang ditulis atas reaksi dari pernyataan mereka di Hamadhan dan al-Darj al-Marqum bin alJadawil (catatan yang tersusun dalam gulungan) yang ditulis untuk menjawab dugaan mereka di Tus. Al-Ghazali juga menulis al-Qistas alMustaqim (keseimbangan yang tepat) yang diharapkan sebagai sebuah tanggapan tidak langsung kepada orang Bathiniyah dan menghadirkan sebuah alternatif sumber pengetahuan yang lain dari pada imam. ${ }^{48}$ Tetapi, menurut Carole Hillenbrand hanya alQisthasal-Mustaqim yang masih ada. Al-Ghazali juga menyerang kaum Ismailiyah juga dalam kitab Mi'yar al-Ilmi, risalah tentang logika yang dikira ditulis tahun 488/1095, lalu Mustasyfa. Menurut Bouyges, Mi'yar al-Ilm lebih dulu ditulis dari Mustazhiry.

Tetapi al-Mustazhiry dipercaya sebagai karya al-Ghazali yang memiliki tujuan khusus untuk menolak keyakinan Ismailiyah. Seperti diketahui, waktu kemunculannya dapat dilihat sebagai hasil meningkatnya hubungan baik dalam satu sisi dalam tubuh Saljuk dan perputaran Khalifah dengan ancaman politis Ismailiyah. Sejawat al-Ghazali, Wazir Agung Saljuk Nizam al-Muluk yang memiliki karya Siyasat-Nama, menampakkan semangat yang membara untuk melawan Ismailiyah. Dia juga mengiringi al-Ghazali dalam satu waktu atas percobaan pembunuhan yang dilakukan oleh Ismailiyah pada 485/1092. Dalam kekuasaan Saljuk, Ismailiyah dibawah pimpinan Hasan al-Sabah telah meraih benteng Alamaut di Timur Laut Iran dan segera mengancam pusat kekuasaan Saljuk. Oleh karena itu tidak mengagetkan, kalau salah satu langkah alMustazhir setelah menjadi khalifah adalah meminta al-Ghazali, seorang tokoh pimpinan teologi pada masanya, untuk menulis buku yang menyerang Ismailiyah yang memiliki propaganda yang canggih. Karya tersebut disambut dengan baik karena dua hal: kecakapan intelektual dan kehendak publik pada waktu itu.

Satu dari dua tujuan utama al-Ghazali dalam karyanya adalah menolak paham Bathiniyah. ${ }^{49}$ Pada bagian buku ini, yang secara luas meliputi bab 2-8, 
telah dijelaskan oleh Goldziher, Laoust. Menurut Carole, kendati Goldziher telah membuat bentuk yang sesuai dalam fokus kajiannya terhadap masalah ini, tapi pendekatannya menimbulkan bias yang besar dalam membahas masalah alGhazali dan kaum Sunni. Seringkali ia tidak membuat perbedaan antara teks alGhazali yang bersifat polemis dengan komentarnya sendiri dalam satu masalah tertentu yang bermusuhan dengan aliran Batiniyah.

Henry Corbin menyarankan Goldziher agar menyeleksi hanya bagian tertentu dari al-Mustazhiry dan mengabaikan hal lain yang tidak sesuai dengan Ismailiyah. Corbin juga mengatakan bahwa respon Ismailiyah terhadap serangan al-Ghazali telah diekspresikan secara mengagetkan karena seorang sarjana sekelas al-Ghazali mengecam mereka tanpa menggunakan referensi yang otentik tentang Ismailiyah. Bukan untuk pertama kalinya, al-Ghazali membuat tuduhan terlalu besar dalam bidang politik pada masanya. ${ }^{50}$

Namun, di antara mereka, Goldziher dan Laoust memberikan instisari yang berharga mengenai argumen yang dikemukakan alGhazali tentang serangannya terhadap doktrin Ismailiyah. Dia menyebut lawannya itu dengan "Ta'limiyyah" atau mereka yang mengikuti ta'lim, sebuah kata yang didefinisikan Corbin sebagai "permulaan pengetahuan" yang diselenggarakan oleh imam yang ma'shum. Menurut al-Ghazali, Ismailiyah percaya bahwa keselamatan terletak pada keyakinan dan yang ditransmisikan imam kepada mereka. Termasuk mengikuti apa yang dilakukan imam.

Bagi Ismailiyah, imam yang tanpa cela adalah wakil Nabi dan setelah kematiannya hanya seseorang dengan kualifikasi tertentu saja dipandang absah menafsirkan wahyu Tuhan. Setiap kurun pasti ada "imam yang ma'shum" (immaculate imam) dan hal itu memang tak dapat dibayangkan bakal ada dua orang imam dalam satu waktu. Bagi Ismailiyah, syari'ah berbeda dengan yang diyakini oleh kaum sunni. Kendati mengikuti syari'ah adalah kewajiban bagi Ismailiyah, tetapi kewajiban yang berdasarkan syariah itu semata-mata ditafsirkan oleh imam mereka. Ini tidak sama dengan pandangan mazhab sunni ortodoks. Ismailiyah menyatakan bahwa imam yang sebenarnya adalah seorang yang menduduki imamah di Mesir dan semua manusia harus memperlihatkan ketaatan kepadanya.

Tujuan lain dari kitab Mustazhiry, yang dalam kenyataannya tak bisa dilepaskan dari tujuan untuk menolak pola imamah Ismailiyah, adalah untuk membuktikan keabsahan Khalifah Abbasiyah alMustazhir. Dalam karangan alGhazali hal itu tampak dalam bab 9 dan 10. Pada bab 9,51 al-Ghazali memulai dengan memperjelas tujuannya, memperlihatkan bahwa Imamah Mustazhir sesuai dengan hukum Islam, bahwa dia adalah khalifah seluruh manusia yang 
kepatuhan kepadanya berdasarkan kewajiban agama (fardhu) yang harus dipatuhi oleh semua manusia. Menurut al-Ghazali, eksistensi Khalifah sebagai kepala pemerintahan merupakan kewajiban yang berdasarkan syariah. Mudahnya, khalifah adalah bandul pemberat legitimasi. Fungsifunsgi publik baru absah jika hal itu bersumber dari kebijaksanaan khalifah yang berkedudukan sangat fundamental dalam menjaga kesinambungan syariah. Jika tidak ada kekhalifahan, semua institusi agama akan mati suri dan syariah akan terancam dan berbahaya. ${ }^{52}$

Al-Gazali membuat tiga argumen untuk mendukung pernyataannya bahwa imam adalah sumber bagi semua legitimasi, di mana bentuk-bentuk yang prinsip mengenai fungsi-fungsi publik bersumber. Pertama berdasarkan kesepakatan umat (ijma)..$^{53}$ Kendati tidak ada kesepakatan mengenai metode yang tepat untuk menetapkan imam, tetapi ada kebulatan suara dalam kewajiban patuh pada imam. Argumen kedua adalah berdasarkan keteladanan yang diberikan para sabahat, dalam rangka menjaga keutuhan umat dan keberlangsungan imam, segera memilih imam setelah wafatnya Rasulullah. ${ }^{54}$ Argumen ketiga adalah kewajiban untuk mentaati penguasa yang semata-mata berbuat berdasarkan kepentingan dirinya bukan atas dasar musyawarah sepanjang pemerintahan tunggal imam itu dalam rangka mencegah terjadinya perpecahan dan pertentangan.

Al-Ghazali selanjutnya beralih untuk membicarakan masalah metode yang tepat untuk menentukan imam. Bagi Ismailiyah, imam ditentukan berdasarkan nash Tuhan. Metode ini tidak dilakukan oleh sejumlah orang yang boleh atau tidak boleh mendukung penunjukan itu. Jika penunjukan dengan nash itu tidak sah, maka dilakukan metode ikhtiyar oleh kaum muslim. Ini bukan metode yang mudah, sepanjang pemilihan ditetapkan dengan dengan ijma kaum muslimin, atau oleh ahl al-hall wa al-aqd di setiap tempat. Hanya ada solusi yang tetap dapat dijalankan yakni dengan melakukan bai'at. Secara pasti al-Ghazali berujar, "Ya, tidak ada rujukan bagi imamah kecuali nash atau pemilihan. Jika nash tidak berlaku, maka melakukan pemilihan itu baik". ${ }^{5}$

Menurut orang-orang Bathiniyah, ada kebutuhan untuk belajar dan juga seorang guru, meskipun tidak semua guru bisa memberikan pengetahuan secara lengkap. Menurut al-Ghazali, alasan mereka itu benar tetapi kesimpulannya salah. Al-Ghazali menemukan hal yang menjadi masalah yaitu alasan yang tepat untuk menentang kesimpulan yang salah. Dia menambahkan, bahwa harus ada seseorang yang menanyakan tentang pengetahuan yang seharusnya mereka peroleh, dan dialah yang melakukannya. Mereka tidak hanya tidak bisa menjawab tetapi juga tidak mengerti dari awalnya, itulah mengapa mereka 
kembali berfikir bahwa hanya imam yang bisa menjawabnya. ${ }^{56} \mathrm{Bagi}$, al-Ghazali, pengajaran (ta'lim) semacam itu bertentangan dengan akal-intelektual. ${ }^{57}$

Sekalipun al-Ghazali di sini agaknya menggantikan taklid dengan otoritas lain, penting dinyatakan bahwa ia mengkritik kaum Bathiniyyah sebagai teolog yang buruk, yang tidak bisa menggunakan logika dengan baik dan secara sembarangan mengubah makna teks-teks suci. Menurut al-Ghazali, para pengikut aliran Bathiniyyah, selain menyembunyikan tujuan-tujuan politis mereka, juga tidak mau mengakui bahwa ajaran-ajaran dan interpretasi mereka atas ajaran al-Qur'an akhirnya akan mengarah pada nihilisme dan peniadaan hukum. ${ }^{58}$ Al-Ghazali memandang bahwa upaya menggantikan penalaran intelektual dengan bukti apodeiktik yang menetapkan kemaksuman para imam adalah menipu dan kontradiktif.59 Sesungguhnya, jika diterima tanpa syarat ucapan-ucapan sang imam, bisa dipastikan sulit dibangun ajaran agama berdasarkan penalaran. ${ }^{60}$

Inti kritik al-Ghazali kepada aliran Bathiniyah ditujukan pada absurditasabsurditas dan bid'ah-bid'ah yang diakibatkan oleh taklid buta kaum Bathiniyah yang diperlihatkan terhadap ajaran otoriter (ta'lim) para imam mereka. ${ }^{61}$ Sesungguhnya, menurut al-Ghazali, satu-satunya petunjuk bagi kaum muslim adalah Nabi Muhammad yang tindakan dan ucapannya membentuk Hadits dan Sunnah dan itu perlu serta cukup untuk mengatur kehidupan komunitas Islam. Seorang Muslim ortodoks hanya perlu mengetahui dua hal saja: salah satunya adalah esistensi Sang Pencipta, wujud yang niscaya, yang tidak membutuhkan pembuat dan pengatur dan kedua adalah kesetiaan kepada Rasul. ${ }^{62}$

\section{Respons Terhadap Kritik Al-Ghazali}

Ancaman politis-ideologis paling destruktif bagi penguasa Abbasiyah abad kesembilan dan kesepuluh muncul dari kalangan Syi'ah. Syi'ah mengartikulasikan doktrin bahwa hanya keturunan Ali Ibn Abi Thlaib (wafat $661 \mathrm{M}^{63}$ yang dianggap absah memerintah kaum muslimin. Kelompok Syi'ah menyatakan bahwa kepemimpinan imam merupakan hal krusial karena ia memiliki kepemimpinan yang bersifat ilahiah (divine sovereignity). ${ }^{64}$ Dalam pandangan mereka kepemimpinan ilahiah ini, di mana setiap imam memberitahukan penggantinya yang terpilih sebelum meninggal, merupakan hal vital dan merupakan petunjuk yang tepat bagi masyarakat muslim. ${ }^{65}$

Namun, di tubuh Syi'ah sendiri pandangan seperti ini tidak seragam. ${ }^{66}$ Kelompok ini pecah menjadi sayap aktivis dan sayap diam (tenang). Kelompok yang diam, biasanya disebut Syi'ah Dua Belas, karena mereka percaya bahwa 
garis imam yang dapat dilihat (hadir) pada 874 ketika imam kedua belas, masih anak-anak, pergi bersembunyi di Samarra. Ia dipercaya akan kembali pada saat yang dijanjikan sebagai Imam Mahdi, ${ }^{67}$ figur millenarian yang diharapkan muncul untuk memimpin masyarakat muslim hingga akhir zaman. Maka, bagi pengikut Syi'ah Dua Belas, tidak ada lagi dasar bagi tindakan politis-ideologis setelah tahun 874, karena itu tidak ada lagi tindak pemberontakan dan anarkisme yang mengatasnamakannya. ${ }^{68}$

Namun demikian, bagi kelompok yang lebih aktif, yakni Ismailiyah, menyatakan bahwa imamah tidak berakhir sebagaimana klaim Syi'ah Dua Belas. Lebih dari itu, Ismailiyah meneruskan tradisi imamah dengan garis keturunan Ali Ibn Abi Thalib dengan varian lain. Dalam pandangan Ismailiyah, tidak pernah berhenti adanya seorang imam yang hidup di antara kaum muslim, sekalipun identitasnya dalam satu saat tertentu mungkin tidak dikenal. Secara periodik, muncul individu-individu yang mengklaim sebagai imam. Dengan demikian jelas bahwa varian doktrin Syi'ah ini cenderung menerima mereka yang berhaluan sebagai aktivis. ${ }^{69}$

Ismailiyah pada awalnya merupakan gerakan yang disatukan oleh ideologi kepemimpinan suci. ${ }^{70}$ Mereka berusaha menarik pengikut dengan sarana da'wah yang dilaksanakan oleh agen-agen yang sangat terlatih dalam argumen teologis. ${ }^{71}$ Tujuan mereka adalah membangun kelompok-kelompok kecil atau komunitas-komunitas pengikut secara rahasia yang dibaiat untuk mengikuti imam ketika muncul. Untuk tujuan ini, mereka tidak boleh mengungkapkan jati diri mereka. Pada akhir abad kesembilan, ketika kekuasaan Abbasiyah mulai melemah, komunitas Ismailiyah terbangun di banyak tempat, seperti di Yaman, Afrika Utara, Iran, Irak Selatan, Arabia Timur dan Syiria. Salah satu kelompok Ismailiyah Qaramithah, ${ }^{72}$ melakukan pemberontakan melawan penguasa Abbasiyah sekitar tahun 890 dan pada tahun 899 membangun sebuah negara kecil di Arabia Timur Laut, namun hanya mampu bertahan hingga sekitar tahun $1070 .^{73}$

Selanjutnya, seperti telah disinggung di muka, golongan Ismailiyah atau Bathiniyah melakukan aksi pembunuhan terhadap para pemimpin negara dan agama ${ }^{74}$ seperti Sultan Maliksyah dan Nizam al-Muluk, Ubaidillah bin Ali alKhutaibi, Abu al-'Alla Sha'id bin Muhammad al-Bukhari, ${ }^{75}$ al-Ruyani, ${ }^{76}$ dan tokoh-tokoh sunni lainnya. ${ }^{77}$ Pasca kematian Maliksyah dan Nizam al-Muluk, hampir semua pemikiran alGhazali tertuju pada polemik anti aliran Bathiniyah ${ }^{78}$ hingga akhirnya al-Mustazhir memerintahkan al-Ghazali untuk menulis sebuah buku yang mengkritik aliran Syi'ah Ismailiyah atau Bathiniyah itu. Seperti telah diungkapkan di muka, karya al-Ghazali itu adalah Fadhāih 
alBāthiniyyah wa Fadhāil al-Mustazhiriyyah, karya polemik yang dikarang berdasar kekeliruan Syi' ah Ismailiyah. ${ }^{79}$

Sebagai karya polemik, kitab al-Mustazhiry mendapat respons secara historis-kritis dari kalangan pendukung Ismailiyah, simpatisan, maupun para ilmuan yang bersifat netral, sejak dulu hingga saat ini. Untuk sekadar menyebutkan contoh sementara, misalnya karya seorang pendukung aliran Bathiniyah, yakni Ali ibn Muhammad al-Walid (w. 612 H/1215 M), Damigh al-Bathil wa Hatfi al-Manadhil, (Beirut: 1974). Lalu karya seorang intelektual Henry Corbin, "The Ismaili Response to the Polemic of al-Ghazali" dalam S.H. Nasr (ed.), Ismaili Contributions to Islamic Culture (Teheran: 1977), hal. 6798. Dan studi Farouk Mitha yang diangkat dari tesis di Universitas McGill Kanada, yakni al-Ghazali and the Ismailis: A Debate on Reason and Authority in Medieval Islam, (London-New York: 2001). Respons tersebut juga bisa ditemui dalam serpihan pemikiran Farhad Daftary dalam sejumlah karyanya, misalnya The Ismailis: Their History and Doctrin (Cambirdge: 1990); The Assassin Legends: Myths of the Ismailis (London: 1994); A Short History of Ismailis (Edinburgh: 1998); dan Medieval Ismaili History and Though (Cambrdge: 1996). Respons juga muncul dalam karya Luke B. Yarbrough, Knowledge of the Heart: Heart of Political Order al-Ghazali on Mysticism and Politics, tesis pada Princeton University Departemen Sejarah, tahun 2004.

Dalam berbagai perspektif, serangkaian respons terhadap pemikiran politik al-Ghazali dalam sejumlah karya di atas dapat diidentifikasi sebagai berikut: (1) Polemik sebenarnya dimulai oleh alGhazali sendiri dengan menyebut Fadhaih untuk al-Bathiniyah dan Fadhail al-Mustazhiriyah; (2) Al-Ghazali dianggap tidak menggunakan sumber rujukan yang otentik dalam menyusun kitab alMustazhiry; (3) Terkait dengan penamaan Bathiniyah, al-Ghazali dipandang kurang memahami konteks sosio-historis pada masanya. Karena jika yang dimaksud al-Ghazali adalah al-Bathiniyah, maka itu berarti bukan Ismailiyah. Alasannya, pada saat al-Ghazali menulis karya polemiknya, Ismailiyah di Iran di kenal dengan istilah al-Da'wa al-Hadiya; (4) Dalam praktik, teori politik alGhazali berbeda dengan realitas politik sesungguhnya.

Tentang respons pertama. Respons kaum Ismailiyah bahwa alGhazali sebenarnya yang telah memancing polemik, karena ia sendiri yang menamakan karyanya dengan Fadhaih (the infamies) untuk al-Bathiniyah dan Fadhail (the virtues $^{80}$ bagi al-Mustazhiriyah, sejauh ini bisa dianggap absah. Secara terbuka al-Ghazali, dengan judul itu, seperti hendak mengatakan bahwa "inilah keburukan atau skandal aliran Bathiniyah dan, sebaliknya, seperti inilah keutamaan khalifah al-Mustazhir dan keluarganya. ${ }^{81}$ Padahal dari sisi al-Ghazali 
sendiri, signifikansi al-Mustazhiry bukan untuk membuka polemik, tapi mengecam gerakan religio-politis yang mengancam eksistensi Abbasiyah sebagai representasi sunni menyusul tewasnya Maliksyah dan Nizam al-Muluk.

Namun, bagi Farouk Mitha, pendekatan al-Ghazali dalam menulis alMustazhiry dinilainya lebih didasarkan pada pra-asumsi al-Ghazali sendiri. Motivasinya telah membangun dan mengkondisikan polemik antara Bathiniyah dan Mustazhiriyah. Oleh karena itu, menurut Farouk Mitha, diperlukan satu upaya untuk mengidentifikasi kembali al-Mustazhiry yang terlanjur bias dan polemis, terutama terkait dengan tujuan dan strategi al-Ghazali vis-à-vis Bathiniyah. Kajian al-Ghazali tentang Bathiniyah dalam bukunya, hendaknya tidak dimulai dengan sikap antipati pada satu hal dan penuh simpati pada hal lain. ${ }^{82}$ Respons Mitha ini, seperti dikatakan Andrew Rippin, karena ia ingin menjadi mitra dialog yang baik antara khalifah dan pendukungnya (maksudnya al-Ghazali) dengan Ismailiyah. ${ }^{83}$ Untuk itu dalam bukunya, Mitha, seperti diungkap Frank Griffel, ${ }^{84}$ berusaha untuk mendalami berbagai segi tentang alGhazali, al-Mustazhiry dan aliran Bathiniyah.

Bila dianalisa, respons Mitha di atas, karena ia menempatkan alMustazhiry hanya sebagai karya di bidang sekte-sekte Islam, bukan karya yang berlatar belakang politik. Dengan demikian, wajar saja bila ia menginginkan al-Ghazali berada pada posisi netral. Dan akibatnya, tulis Frank Griffel, ${ }^{85}$ Mitha banyak menolak argumen-argumen alGhazali dalam bukunya. Jadi, tampaknya bagi Farouk Mitha, peristiwaperistiwa yang terjadi seperti kematian Maliksyah dan Nizam al-Muluk dan berbagai ancaman dan pembunuhan para petinggi agama dan negara dalam kekuasaan Abbasiyah dan Saljuk dianggap belum cukup bagi al-Ghazali untuk mengatakan Fadhaih (the infamies) untuk alBathiniyah dan Fadhail (the virtues) bagi al-Mustazhiriyah.

Terlepas dari respons Mitha, para ahli sejarah memberikan informasi bahwa al-Mustazhiry dianggap berhasil meredam penetrasi Bathiniyah di dalam tubuh pemerintahan Abbasiyah dan Saljuk. Indikasinya, khalifah al-Mustazhir dapat mempertahankan kekuasaannya hingga 25 tahun, padahal sejak tahun kedua ia naik tahta, al-Ghazali sudah meninggalkan Baghdad. Lalu, hubungan kekhalifahan Abbasiyah dan kesultanan Saljuk relatif harmonis karena diikat oleh semangat memegang teguh paham sunni, sehingga gerakan Bathiniyah, yang didentifikasi sebagai Syi ah, dianggap sebagai musuh bersama yang bersifat permanen. Argumentasi untuk hal ini, bisa dijelaskan: (1) karena al-Mustazhiry selain berdimensi religio-politis, juga dapat dipandang sebagai karya di bidang kalam yang membela paham sunni, dan (2) al-Mustazhiry juga berisi yuridis- 
politis, dalam konteks alGhazali sebagai seorang juris yang dekat dengan istana dan kerap-kali memberikan justifikasi bagi urusan negara dan kekuasaan politik.

Tentang respons kedua. Menurut Ali Ibn Muhammad al-Walid dalam Damigh al-Bathil wa Hatfi al-Manādhil, tulisan al-Ghazali dalam al-Mustazhiry hanya didasarkan pada tuduhan dalam kumpulan tulisan para penyusun bid'ah, al-Ghazali tidak pernah merujuk satu pun sumber Ismailiyah yang otentik. Kenyataannya memang demikian, al-Ghazali dalam al-Mustazhiry mengaku telah membaca buku-buku aliran Bathiniyah tanpa menyebut sumber yang dibaca. Al-Ghazali pernah menyatakan dalam Ihya bahwa ia mendapatkan informasi tentang Ismailiyah dari karya al-Baqillani, tokoh sunni yang juga menyerang aliran Bathiniyah. Kritisisme al-Walid, secara ilmiah bisa dianggap valid, hanya saja dia sendiri tidak menyebutkan satu pun sumber Ismailiyah yang otentik yang harus dipelajari al-Ghazali.

Dalam al-Munqidz, al-Ghazali mengaku bahwa kritik tajam yang dialamatkan kepada aliran Bathiniyah tidak hanya diekspresikan dalam alMustazhiry saja. Seperti telah dikutip di muka, karya al-Ghazali yang menyerang aliran Bathiniyah adalah Hujjat al-Haq atau sering disebut dengan Hujjat al-Bayan, Mufashshal al-Khilaf, al-Darj al-Marqum bi al-Jadawil. ${ }^{86}$ Di samping sejumlah karya di atas, berdasar pengamatan Yusuf Qardhawi, alGhazali juga menulis sebuah kitab yang berjudul al-Qisthas al-Mustaqim. Kitab ini merupakan kitab tersendiri, yang di dalamnya berisi tentang neraca ilmu pengetahuan, dan penjelasannya berisi tentang tidak perlunya imam yang dianggap ma'shum. Karya ini, jika dianalisa, ditujukan kepada mereka yang telah meyakini paham Bathiniyah, di smaping itu karya lainnya dengan tujuan serupa adalah Qashim al-Bathiniyah dan Mawahim al-Bathiniyah. ${ }^{87}$

Semua karya al-Ghazali di atas yang menyinggung aliran Bathiniyah, bila dikaitkan dengan pendapat al-Walid, berarti tidak memiliki otentisitas ilmiah yang memadai. Tetapi, masalahnya adalah: apakah benar sejumlah karya di atas yang ditulis oleh seorang ilmuan besar tidak memiliki sumber rujukan yang bisa dipertanggungjawabkan? Ada beberapa kemungkinan mengenai hal ini. Pertama, seperti diutarakan al-Ghazali dalam Ihya dan al-Mustazhiry, sumber yang dibaca dan disebut sebagai karya al-Baqillani adalah al-Farq bayn al-Firaq, di mana diketahui menentang aliran Bathiniyah. ${ }^{88}$ Sampai di sini tampaknya respons kritis al-Walid sebegitu jauh bisa dianggap absah.

Kedua, diduga al-Ghazali mengenal The Four Points karya Hasan alSabah, ${ }^{89}$ satu-satunya tulisan kelompok Ismailiyah yang diketahui namanya, dan diketahui juga dengan baik oleh al-Ghazali. Ketiga, dalam al-Munqīdz, alGhazali menyebutkan selain "tulisan-tulisan mereka", ada dua buah sumber 
lisan. Salah satunya adalah sumber yang oleh al-Ghazali disebut "seorang sahabat yang sering berkumpul bersamanya setelah ia bergabung dengan mereka dan mengakui doktrindoktrin mereka”. Berdasar argumentasi ini, al-Ghazali tampaknya tidak hanya mendasarkan sejumlah karyanya pada karya al-Baqillani semata. Apalagi, dalam al-Munqìdz ia mengaku memiliki sumber lisan, kendati otentisitasnya masih perlu ditelusuri karena al-Ghazali tidak menyinggung tentang identifikasi dan spesifikasi "seorang sahabat itu" dan "doktrin-doktrin mereka”.

Tentang respons ketiga. Terkait dengan penamaan Bathiniyah, al-Ghazali dipandang kurang memahami konteks sosio-historis pada masanya. Karena jika yang dimaksud al-Ghazali adalah al-Bathiniyah, maka itu berarti bukan Ismailiyah. Alasannya, pada saat al-Ghazali menulis karya polemiknya, Ismailiyah di Iran di kenal dengan istilah al-da'wah al-hadiyah atau the rightly guiding mission. Menurut alSyahrastani, seperti dikutip Mitha, ${ }^{90}$ Ismailiyah di Iran dikenal juga dengan nama al-da'wah al-jadidah atau the new mission. Tapi, meminjam argumentasi Bernard Lewis, alasan al-Ghazali menamakan Ismailiyah sebagai Bathiniyah terkait doktrin Ismailiyah tentang pengetahuan dan tindakan rahasia di mana selanjutnya pengetahuan ini dikenal dengan nama ta'wil al-bathin, penafsiran esoteris, salah satu ciri sekte Ismailiyah yang kemudian memunculkan istilah Bathiniyah. ${ }^{91}$

Dalam kaca mata sejarah, seperti diungkap Antony Black, alda'wah aljadidah adalah gerakan politik keagamaan yang dipimpin oleh Hasan al-Sabah, seorang pemimpin misionaris Ismailiyah yang proFathimiyah di Iran. Ia terus menggalang kekuatan untuk menegakkan institusi imamah, sebagai respons terhadap kampanye militer Saljuk yang dirancang untuk menerapkan kebijakan Sunni dan mengikis habis kaum Ismailiyah yang dianggap sebagai pembuat bid'ah. Dari Alamut, Hasan al-Sabah mensponsori pemberontakan dan menyusun rencana untuk membunuh para penguasa dan ulama Sunni, ${ }^{92}$ seperti Maliksyah dan Nizam al-Muluk.

Berdasar argumen di atas, Bernard Lewis tampaknya membenarkan penamaan Bathiniyah untuk Ismailiyah. Sedangkan dari paparan Bernard Lewis dan Antony Black, dapat dikemukakan bahwa Ismailiyah adalah kaum Bathiniyah yang dipimpin oleh Hasan al-Sabah dengan menggunakan nama alda'wah al-jadidah. Dan karena Hasan al-Sabah dan kelompoknya kerap kali melakukan pembunuhan, seperti berkalikali diungkap di muka, maka dinamakan sebagai Assassin yang berarti pembunuh. Dalam catatan Antony Black, strategi politik keagamaan mereka dengan cara menggulingkan para penguasa dan para pemimpin Sunni. Tujuan mereka adalah melakukan 
pemberontakan demi kepentingan Imam Fathimiyah yang sejati yaitu Imam Nizar. ${ }^{93}$

Sejumlah sarjana, seperti Henry Corbin ${ }^{94}$ dan Frank Griffel, ${ }^{95}$ menyatakan bahwa labelisasi Bathiniyah adalah ungkapan peyoratif bagi Ismailiyah yang sengaja dibuat al-Ghazali. Dikatakan demikian, karena mereka dipandang hendak mengesampingkan ketentuanketentuan syariat dan mendasarkan setiap tindakannya pada maknamakna esoterik. Al-Walid dalam Damigh al-Bathil menolak tuduhan ini dan dengan panjang lebar membela sekte Ismailiyah dari tuduhan mengingkari syariat. Al-Walid menolak sama-sekali generalisasi yang dibuat al-Ghazali terhadap Ismailiyah, apalagi mengaitkan Ismailiyah dengan berbagai gerakan religius dan spiritual seperti Karmathian dan Babakiyah.

Menurut al-Walid, seperti dikutip Corbin, ${ }^{96}$ jika al-Ghazali menyebut Ismailiyah dengan Bathiniyah, itu memang karena Ismailiyah meyakini bahwa untuk setiap makna eksoterik dari al-Qur'an, terdapat suatu pengertian esoterik yang merupakan sebagai makna hakiki. Hal itu merupakan kepercayaan Ismailiyah yang kuat, dan merupakan bentuk pengabdiannya kepada Tuhan. Ismailiyah juga percaya pada apa yang difirmankan Allah dalam al-Qur'an, dan apa yang diserukan Muhammad saw kepada manusia. Untuk tujuan penyebarluasan seruan itu, Nabi saw telah mengangkat para penerus spiritual serta para imam yang ma'shum. Tetapi, Richard McCarthy mempertegas, sebutan Bathiniyah atau esoterik bagi Ismailiyah hanya cemoohan, ${ }^{97}$ bukan dalam pengertian sebenarnya.

Tentang respons keempat. Dalam praktik, teori politik al-Ghazali berbeda dengan realitas politik sesungguhnya. Misalnya, dalam tataran abstrak, alGhazali menyatakan bahwa khalifah sebagai saluran kekuasaan Ilahi sekaligus sebagai pemberi kekuasaan yang harus ditaati karena telah menciptakan sebuah ketertiban masyarakat. Namun ketika didaratkan secara praktis, model yang alGhazali kemukakan itu berbeda. Al-Ghazali justru membela status-quo dan memuji pemerintahan pada masanya. Tak hanya itu al-Ghazali juga menunjukkan komitmennya yang bersifat absolut kepada penguasa. Alasannya hanya karena ia takut terjadi chaos, apabila ia tidak memberikan pembelaan terhadap khalifah atau sultan yang sedang berkuasa, seperti yang pernah terjadi sebelumnya. ${ }^{98}$

Selanjutnya, menurut Yarbrough, al-Ghazali juga harus menjawab satu pertanyaan: "Ada banyak personal yang dipandang mampu menjadi khalifah, tetapi mengapa al-Ghazali hanya menunjuk al-Mustazhir sebagai calon tunggal?" Menurut Yarbrough, ia tidak menemukan informasi mengenai hal itu dalam karya al-Ghazali selain pembelaan dan pujian al-Ghazali kepada al- 
Mustazhir. Menurut al-Ghazali tantangan yang mungkin muncul dan berbahaya bagi supremasi alMustazhir adalah kaum Ismailiyah. Dan secara panjang lebar pada bab kedelapan dalam al-Mutazhiry ia membuktikan berbagai invaliditas teori imamah Ismailiyah dan menyimpulkan bahwa alMustazhir, kata al-Ghazali, satu-satunya khalifah terbaik dan sah (rightful). ${ }^{99}$

Selanjutnya, menurut Yarbrough, al-Ghazali memandang bahwa, khalifah adalah seorang pemimpin yang dipilih (choice/ikhtiyar/election) oleh rakyat berdasarkan atas komitmen mereka untuk mematuhinya. ${ }^{100} \mathrm{Al}$-Ghazali menolak sama-sekali pandangan Syi'ah yang menyatakan imamah adalah hak mutlak imam ma'shum yang dipilih langsung oleh Tuhan berdasarkan nash (textual designation) melalui garis keturunan Ali bin Abi Thalib. Menurut Yarbrough, dalam praktik, teori politik al-Ghazali berbeda dengan realitas politik sesungguhnya, ternyata alGhazali mendukung, atau tepatnya melegitimasi, pemerintahan Bani Abbasiyah yang ternyata bukan berdasar (choice/ikhtiyar/election) maupun nash (textual designation).

Yarbrough juga merespons pandangan al-Ghazali tentang syaratsyarat yang dianggapnya tidak konsisten. Dalam al-Mustazhiry, ${ }^{101}$ hanya membuat empat syarat saja bagi khalifah al-Mustazhir), yaitu (1) najdat, yakni memiliki cukup kekuatan dan berwibawa, (2) kifayah, yaitu mampu menyelesaikan segala persoalan, (3) wara', yaitu sikap hidupnya, (4) 'ilm, memiliki ilmu pengetahuan. Al-Ghazali menyatakan bahwa bagi al-Mustazhir najdat bisa didapat dari kekuatan militer bangsa Turki, yakni Saljuk. Tentang syarat 'ilm, al-Ghazali mengatakan syarat tersebut bisa dipenuhi dengan bantuan para ahli ilmu pengetahuan di bidangnya. Menurut Yarbrough, dalam praktik, teori politik alGhazali berbeda dengan realitas politik pada masanya. Ternyata al-Ghazali tidak sungguh-sungguh menyerahkan kendali najdat kepada Sultan Saljuk. ${ }^{102}$

\section{Kesimpulan}

Respons terhadap respons Yarbrough di atas, dapat diungkapkan sebagai berikut: Pertama teori al-Ghazali mengenai pengangkatan kepala negara disandarkan pada metode penerapan dari peristiwa semasa hidupnya yang bersentuhan langsung dengan para khalifah Bani Abbasiyah dan para Sultan Bani Saljuk. Lalu, secara teologis, tampaknya al-Ghazali lebih suka menoleh pada apa yang telah dipraktikkan oleh Nabi Muhammad, para sahabat, dan tabiin. Dan secara praksis, al-Ghazali sendiri setuju dengan yang dilakukan secara turun-temurun dalam prakatik penyelenggaraan negara dan kekuasaan khilafah Dinasti Abbasiyah. 
Kedua, untuk memelihara integritas Dunia Islam, al-Ghazali berusaha mengokohkan teori kompromi mengenai kekhalifahan. Al-Ghazali berkata bahwa khilafah dapat ditegakkan melalui ayat yang disampaikan Nabi, melalui pewarisan kekuasaan dari khalifah yang sedang bekuasa, melalui penghibah otoritas (tafwidh) kepada seorang kuat yang karena kepatuhannya dan karena otoritas yang dihibahkan kepadanya itu sanggup memperoleh persetujuan orang lain sehingga bersedia memberikan sumpah setia. Al-Ghazali mengenalkan suatu pendekatan realistik dalam melakukan rekonsiliasi antara idealitas agama dan realitas penyelenggaraan negara.

Respons aliran Bathiniyah terhadap pemikiran politik al-Ghazali bersumber dari karya polemiknya, yaitu Fadhāih al-Bāthiniyyah wa Fadhāil alMustazhiriyyah. Karya al-Ghazali ini mendapat respons secara historis-kritis dari kalangan pendukung Ismailiyah, simpatisan, maupun para ilmuan yang bersifat netral, sejak dulu hingga saat ini. Misalnya dari Ali ibn Muhammad alWalid dalam karyanya Damigh al-Bathil wa Hatfi al-Manadhil. Lalu dari Henry Corbin "The Ismaili Response to the Polemic of al-Ghazali" dalam S.H. Nasr (ed.), Ismaili Contributions to Islamic Culture dan studi Farouk Mitha yakni AlGhazali and the Ismailis: A Debate on Reason and Authority in Medieval Islam. Respons juga muncul dari Luke B. Yarbrough dalam Knowledge of the Heart: Heart of Political Orderal- Ghazali on Mysticism and Politics. Secara umum mereka menolak pemikiran politik al-Ghazali yang tertuang dalam kitab Fadhāih al-Bāthiniyyah waFadhāil alMustazhiriyyah.

Dalam berbagai perspektif, respons negatif mereka terhadap pemikiran politik al-Ghazali dapat diidentifikasi sebagai berikut: (1) Terkait penyebutan al-Ghazali Fadhāih untuk al-Bathiniyah dan Fadhāil al-Mustazhiriyah; (2) AlGhazali dianggap tidak menggunakan sumber rujukan yang otentik dalam menyusun kitab al-Mustazhiry; (3) Terkait dengan penamaan Bathiniyah, alGhazali dipandang kurang memahami konteks sosio-historis pada masanya. Karena jika yang dimaksud al-Ghazali adalah al-Bathiniyah, maka itu berarti bukan Ismailiyah. Alasannya, pada saat al-Ghazali menulis karya polemiknya, Ismailiyah di Iran di kenal dengan istilah al-Da'wa al-Hadiya; (4) Dalam praktik, teori politik al-Ghazali berbeda dengan realitas politik sesungguhnya. 


\section{Daftar Pustaka}

Abdullah, M. Amin, Antara al-Ghazali dan Kant: Filsafat Etika Islam, (Bandung: Mizan, 2002).

Atsir, Ibn, al-Kāāmil fỉ al-Tarīkh, (Beirut: Dār Beirut-Dār Shadr 1966), Jilid 10, Al-Ghazali, al-Iqtishād fi al-I'tiqād, (Beirut-Libanon: Dar al-Kutub al'Ilmiyyah, 1988).

Al-Ghazali, al-Munqidz min al-Dhalāl, (Damaskus: t.p., 1934).

Al-Ghazali, Fadhāih al-Bāthiniyyah wa Fadhāil al-Mustazhiriyyah, (Kairo: alDar al-Qaumiyah li al-Thaba'ah wa al-Nasyr, 1974).

Al-Ghazali, Ihyā' 'Ulūm al-Dīn, (Beirut: Dār al-Fikr, 1975).

Al-Qayyūm, Abd., Letters of al-Ghazzali (New Delhi: Kitab Bhavan, 1992).

Ahmad, Zainal Abidin, Konsepsi Negara Bermoral Menurut Imam alGazali, (Jakarta: Bulan-Bintang, t.th.).

Ahmad, Zainal Abidin, Riwayat Hidup Imam al-Ghazali, (Jakarta: Bulan Bintang, 1975).

Al-A'sham, Abd al-Amir, al-Failasūf al-Ghazāli, (Kairo: Dār Qabāi li alThabā'at wa al-Nasyr, 1988).

Badawi, 'Abd. Al-Rahman Badawi, Mu'allafat al-Ghazāli, (Kairo: t.p., 1961).

Al-Baghdadi, Mu'jam al-Buldān, (Beirut: Dār Shādar, 1977), Jilid 4.

Basil, Sa'id, Manhāj al-Bahsi 'an Ma'rifat 'ind al-Ghazāli, (Beirut: Dār alKitāb al-Banani, t.t.).

Binder, Leonard, Islamic Liberalisme: A Critique of Development Ideologies, (Chicago: The University of Chicago Press, 1988).

Black, Antony, The History Islamic Political Thought: From the Prophet to the Present, (Edinburgh: Edinburgh University Press, 2001).

Basil, Sa'id, Manhaj al-Bahsi 'an Ma'rifat 'Inda al-Ghazali, (Beirut: Dar al-Kitab al-Banani, t.t.).

Bosworth, CE., The New Islamic Dynasties: A Cronological and Geneological Manual, (Edinburgh: Edinburgh University Press, 2004), hal. 6.

Bouyges, Maurice, Essai de Chronologie des oeuvres de al-Ghazali, (Beirut: Imprimerie Catholique, 1959).

Campanini, Massimo "Al-Ghazali", dalam Sayyed Hossein Nasr dan Oliver Leaman, Ensiklopedi Tematis Filsafat Islam, (Bandung: Mizan, 2003).

Corbin, Henry, "The Ismaili Response to the Polemic of al-Ghazali" dalam S.H. Nasr (ed.), Ismaili Contributions to Islamic Culture (Teheran: t.p, 1977). 
Daftary, Farhad, The Ismailis: Their History and Doctrin (Cambirdge: Cambridge University Press, 1990).

Daftary, Farhad, The Assassin Legends: Myths of the Ismailis (London:1994);

A Short History of Ismailis (Edinburgh: Edinburgh University Press, 1998).

Daftary, Farhad, Medieval Ismaili History and Though (Cambrdge: Cambridge University Press 1996)

dan; Intellectual Traditions in Islam (London: 2000).

Daftary, Farhad, Ismaili Literature: A Bibliography of Sources and Study, (London-New York: I.B. Taurits Publishers, 2004).

Daftary, Farhad, "Ismaili Studies: Medieval Antecedents and Modern Deevelopment", The Institute of Ismail Studies, 2002.

Dunya, Sulayman, al-Haqīah fi Nadhri al-Ghazāli, (Kairo: Dar alMa'arif, 1965).

Endress, Gerhard, dan Hillenbrand, Carole, Islam: An Historical Introduction, (Edinburgh: Edinburgh University Press, 2002), hal. 172.

Al-Farisi, al-Muntakhab min al-Siyāk li Tārikh Naisābūr, (Beirut: Dār al-Kutūb al-'Ilmiyyah, 1989).

Al-Fida', Abu, al-Tibr al-Masbūk fi Tawarikh al-Mulūk, (Kairo: Maktabah alTsaqafat al-Diniyah, 1995).

Fisher, William Bayne, The Cambridge History of Iran, (Cambridge: Cambridge University Press, 1968).

Grunebaum, G. E. Von, Classical Islam: A History 680-1258, (Chicago: Aldine Publishing Company, 1970).

Hillenbrand, Carole, "Islamic Orthodoxy or Realpolitik?; al-Ghazali's views on government", London, Iran; Journal of the British Institute of Persian Studies, 1988.

Hilmi, A. Kamaluddin, al-Salājiqah fi al-Tarīkh wa al-Hadharah, (Kuwait: Dār al-Buhuts al-'Ilmiyyah, tt).

Jabre, Farid, Essai sur le lexique de Ghazali, (Beirut: Publications de L'Universite Libanaise, 1985).

Jabre, Farid, La notion de certitude selon ghazali: Dans ses orgines psychologiques et historiques, (Paris: Libraire Phiosophique, 1988).

Jabre, Farid, La notion de certitude selon Ghazali: Dans ses orgines psychologiques et historiques, (Paris: Libraire Phiosophique, 1988).

Katsir, Ibn, al-Bidāyah wa al-Nihāyah, (Beirut: Dār al-Kutub al'Ilmiyyah, t.t.) juz 12.

Lewis, Bernard, The Political Language of Islam, (Chicago and London: The University of Chicago Press, 1988). 
Lewis, Bernard, The Assassins: A Radical Sect in Islam, (New York: Oxford University Press, 1967).

McCarthy, Richard J., al-Mustazhari being a Translation of Fadaih al-Bathiniya wa Fadhail al-Mustazhiriyah of al-Ghazali with Translation and Annotation, (New York:Twayne Publishers, 1980).

Mitha, Farouk, al-Ghazali and the Ismailis: A Debate on Reason and Authority in Medieval Islam, (London-New York: I.B. Taurits Publishers, 2001). Mugni, A. Syafiq, Sejarah Kebudayaan Islam di Turki, (Jakarta: Logos, 1997). Al-Najjar, Amir, Nadzarat fī Fikr al-Ghazāli, (Ttt: Syirkah al-Shafaa, tth). Al-Qadhi, Ahmad Arfat, al-Fikr al-Siyāsiy 'ind al-Bāthiniyyahwa Mauqifu alGhazāli, (Kairo: Hai'at al-Mishriyyat al-'Ammah li alKitāb, 1993).

Qardhawi, Yusuf, al-Imām al-Ghazāli baina Madhīhiyah wa Naqidhiyah (alManshūrah: Dār al-Wafa', 1992).

Review book atas karya Farouk Mitha oleh Andrew Rippin, dalam Journal Studies in Religion, 31, 2, 2002.

Review book atas karya Farouk Mitha oleh Frank Griffel, dalam Journal of Semitic Studies, 48, 2003.

Rosenthal, Erwin I.J., Islam in the Modern National State, (Cambridge: Cambridge University Press, 1965).

Sway, Mustafa Abu al-Ghazali: A Study in Islamic Epistemology, (Kuala Lumpur: Dewan Bahasa dan Pustaka, 1996).

Sjadzali, Munawir, Islam dan Tata Negara: Ajaran, Sejarah, dan Pemikiran, (Jakarta: UI Press, 1993).

Al-Suyuthi, Jalaluddin, Tarīkh al-Khulafa', (Beirut: Dar al-Arqam, t.th.). Souyb, Joesoef Sejarah Daulat Abbasiyah III, (Jakarta: Bulan Bintang, 1976). 'Utsman, Abd al-Karim, Sirāh al-Ghazāli wa Aqwāl al-Mutaqaddimin fih, (Damaskus: t.p. 1961).

Al-Walid, Ali ibn Muhammad, Dāmigh al-Bāthil wa Hadfi al-Manadhil, (Beirut: 'Izz al-Din, 1974).

Watt, W. Montgomery, Islamic Political Thought, (Edinburgh: Edinburgh University Press, 1960).

Watt, W. Montgomery, Islamic Philosophy and Teologhy, (Edinburgh: Edinburgh University Press, 1987).

Watt, W. Montgomery, Muslim Intellectual: A Study of al-Ghazali, (Edinburgh: Edinburgh University Press, 1963)

Yarbrough, Luke B.,Knowledge of te Heart: Heart of Political Order alGhazali on Mysticism and Politics, Tesis pada Princeton University Departemen Sejarah, 2004. 
Young, M. J. L., Religion, Learning and Science in the Abbasid Period, (Cambridge: Cambridge University Press, 2006).

Zaidan, Jurji, Tarīkh al-Tamaddun al-Islāmi, (Beirut: Dār Maktabah al-Hayah, 1967), Juz. 2.

Zaqzuq, Mahmud Hamdi, al-Manhaj al-Falsafi Baina al-Ghazali wa Dikart, (Kairo: Dar al-Ma’arif, 1997)

\section{Endnotes}

1 Nama lengkapnya adalah Abu Hamid Muhammad bin Muhammad bin Muhammad bin Ta'us al-Thusi al-Syafi'i al-Ghazali. Uraian seperti ini lihat, misalnya, Sa'id Basil dalam Manhaj al-Bahsi 'an Ma'rifat 'Inda al-Ghazali, (Beirut: Dar al-Kitab al-Banani, t.t.) hal. 16. Untuk mendapatkan informasi lebih jelas mengenai biografi al-Ghazali, baca Abd alKarim 'Utsman, Sirat alGhazāli wa Aqwāl al-Mutaqaddimin fîh, (Damaskus: t.p. 1961); Al-Ghazali, al-Munqīdz min al-Dhalāl, (Damaskus: t.p., 1934); Sulaiman Dunya, alHaqīqah fi Nadhri al-Ghazāli, (Kairo: Dar al-Ma'arif, 1965); W. Montgomery Watt, Muslim Intellectual: A Study of al-Ghazali, (Edinburgh: t.tp., 1963); Zainal Abidin Ahmad, Riwayat Hidup Imam al-Ghazali, (Jakarta: Bulan Bintang, 1975); Yusuf Qardhawi, al-Imām al-Ghazāli baina Madhīhiyah wa Naqidhiyah (al-Manshūrah: Dār alWafa', 1992); Syed Nawab, Some Moral and Religious Teaching of al-Ghazali, (Lahore: S.H. Muhammad Ashraf, 1980).

2 Ada yang berpendapat kata "al-Ghazali" adalah julukan yang mengacu kepada tempat kelahiran al-Ghazali, yakni sebuah kampung bernama Ghazlah di Khurasan, Iran. Telusuri T.J. De Boer, The History of Philosophy in Islam, (Chapel Hill: The University of North Carolina Press, 1975), hal. 93; W. Montgomery Watt, "Al-Ghazali", TheEncyclopaedia of Islam, (E.J. Brill: Leiden, 1965), hal. 1038. Untuk studi lebih lanjut mengenai al-Ghazali lihat entri "al-Ghazali" dalam Encyclopaedia of Philosophy, Encyclopaedia of Religion, Encyclopaedia of Islam, Encyclopaedia of Iranica, Encyclopaedia of Britannica, dan Stanford Encyclopaedia of Philosophy.

3 Lihat Abd al-Qayyum, Letters of al-Ghazzali (New Delhi: Kitab Bhavan), hal. 1. Karya alGhazali ini ada yang menyebutnya dengan Fadhāil al-Anam min al-Rasāil Hujjat alIslām.

4 Tentang Thus, lihat al-Baghdadi, Mu’jam al-Buldān, (Beirut: Dār Shādar, 1977), Jilid 4, hal. 49.

5 Informasi tentang yang dilakukan al-Ghazali di Naisabur, lihat al-Farisi, al-Muntakhab min al-Siyāk li Tārikh Naisābūr, (Beirut: Dār al-Kutūb al'Ilmiyyah, 1989), hal. 73.

6 Al-Juwaini adalah salah seorang guru paling berpengaruh bagi al-Ghazali. AlGhazali menguasai ilmu mantiq, ilmu kalam, fikhi dan ushul fikih, filsafat, dan tasawuf dari Imam Haramain ini. M.M. Syarif, A History of A Moslim Philosophy Vol I (Weisbaden: t.p., 1963), hal. 583-584. Menurut Antony Black, al-Juwaini adalah seorang pengikut Asy'ari terkemuka yang pernah diusir dari Naysyabur oleh penguasa Saljuk karena pandangannya yang pro Muktazilah, namun kemudian namanya direhabilitasi. Lihat Antony Black dalam The History Islamic Political Thought: From the Prophet to the Present (Edinburgh: Edinburgh University Press, 2001), hal. 188. 
7 Tentang sepak terjang al-Ghazali di Baghdad, lihat Abd al-Amir al-A'sham, alFailasūf...hal. 36-40.

8 Ibn 'Aqil yang dimaksud adalah seorang ahli ilmu nahwu, lihat Jalaluddin al-Suyuthi, Tarīkh al-Khulafa', (Beirut: Dar al-Arqam, t.th.) hal. 338. Bandingkan dengan Ibn Katsir, al-Bidāyah wa al-Nihāyah, (Beirut: Dar alKutub al-'Ilmiyah, t.th.) juz 12, hal. 156.

9 Para penguasa Saljuk, seperti juga Al-Ghazali, menganut mazhab Syafi'iyyah dalam hukum (fikih) dan bermazhab Asy'ariyyah dalam teologi. Di bawah kepemimpinan para penguasa penganut mazhab yang sama, al-Ghazali kelak menikmati segala kehormatan. Tokoh politik terpenting yang dihubungkan dengan keilmuan al-Ghazali adalah Nizam al-Mulk, seorang wazir (setingkat perdana menteri), yang memangku jabatan selama sekitar 30 tahun sejak masa pemerintahan Alparslan sampai pada pemerintham Malik Syah. Ia menstabilkan Saljuk dan sukses meredakan ketegangan atau konflik keagamaan yang sebelumnya terjadi secara tajam antar berbagai mazhab fikih dan kalam. Lihat, Sibawaihi, Eskatologi al-Ghazali dan Fazlur Rahman: Studi Komparatif Epistemologi Klasik-Kontemporer, (Yogyakarta: Islamika, 2004), hal. 34.

10 Antony Black, The History of Islamic Political Thought ...hal. 97. M. Amin Abdullah, Antara al-Ghazali dan Kant: Filsafat Etika Islam, (Bandung: Mizan, 2002), hal. 29.

11 Untuk mengetahui lebih jauh tentang Dinasti Saljuk berikut wilayah kekuasaannya yang masing-masing dipimpin oleh seorang sultan lihat Clifford Edmund Bosworth, The Islamic Dynasties: A Cronological and Genealogical Handbook, (Edinburgh: Udinburgh University Press, 1980), hal. 155-128. Bandingkan dengan Jurji Zaidan, Tarikh alTamaddun al-Islami, (Beirut: Dar Maktabah al-Hayah, 1967), Juz. 2, hal. 473.

12 Penting untuk disebutkan di sini bahwa terdapat dua Madrasah atau Universitas Nizamiyahyang didirikan oleh Nizam al-Mulk, yang satu berada di Baghdad dan yang lainnya di Naysyabur. Al-Ghazali menyetujuinya dan iapun kembali kepada kehidupan kemasyarakatan pada 1106 M. Abd al-Qayyum, The Letters of...hal. 5.

13 Al-Ghazali menulis bukunya ini pada usia lima puluh tahun, setelah menjelajahi semua aliran fikih, kalam, filsafat, dan mengkaji berbagai pendapat sekte-sekte secara saksama, dan dia tidak melihat satu jalan dari semua itu yang dapat mengantarkannya kepada makrifat, kecuali jalan sufistik. Tentang sejumlah karya al-Ghazali dan kritik terhadap otentisitasnya baca 'Abd. al-Rahman Badawi, al-Muallafat al-Ghazāli, (Kairo: t.p., 1961); Maurice Bouyges, Essai de Chronologie des oeuvres dem al-Ghazali,(Beirut: Imprimerie Catholique, 1959); George F. Hourani, “A Revised Chronology of al-Ghazali’s Writing”, Journal of the American Oriental Society, 104, 2, 1984. dan W. Montgomery Watt dalam "The Authenticity of the Works Atributed to al-Ghazali", Journal of the Royal Asiatic Society, 4, 1952.

14 M. Amin Abdullah, Antara al-Ghazali dan Kant... hal 31.

15 Selengkapnya baca Mahmud Hamdi Zaqzuq, al-Manhā al-Falsafi Bayna alGhazāli wa Dikart, (Kairo: Dar al-Ma'arif, 1997), hal. 9.

16 A. Syafiq Mugni, Sejarah Kebudayaan Islam di Turki, (Jakarta: Logos, 1997), hal. 2.

17 Joesoef Souyb, Sejarah Daulat Abbasiyah III, (Jakarta: Bulan Bintang, 1976), hal. 6-8. Bandingkan dengan uraian, Ahmad Syafii Ma'arif, Islam dan Masalah Kenegaraan, (Jakarta: LP3ES, 1987), hal. 16.

18 Munawir Sjadzali, Islam dan Tata Negara, (Jakarta: UI Press, 1990) hal. 72. Informasi memadai mengenai pengertian masing-masing istilah tersebut bisa dilihat dalam Bernard 
Lewis, The Political Language of Islam, (Chicago and London: The University of Chicago Press, 1988), terutama mulai hal. 43.

19 Joesoef Souyb, Sejarah Daulat ..., hal. 7-8.

20 A. Kamaluddin Hilmi, al-Salajiqah fi al-Tarikh wa al-Hadharah, (Kuwait: Da al-Buhuts al-'Ilmiyyah, tt), hal. 217-219.

21 Dikutip dari Lukman Farouni, "Pemikiran Politik al-Ghazali: Studi Historis Kritis", Surabaya, Jurnal ISIP, Vol. 2. No. 15, Desember 2000- Februari 2001.

22 Jalaluddin al-Suyuthi, Tarikh al-Khulafa', (Beirut: Dar al-Arqam, t.th.) hal. 335.

23 Ibn Atsir, al-Kamil fi al-Tarikh, (Beirut: Dar Beirut-Dar Shadr 1966), Jilid 10, hal. 231. Lihat juga Thomas F. Glick, Medieval Science, Technology, and Medicine: An Encyclopedia, (: Routlegde, 2005), hal. 194.

24 Lihat C.E. Bosworth, The New Islamic Dynasties: A Cronological and Geneological Manual, (Edinburgh: Edinburgh University Press, 2004), hal. 6. Lihat juga Julie Scott Meisami dan Paul Starkey, Encyclopedia of Arabic Literature, (London and New York: Routledge, 1998), hal. 836.

25 Thomas William Beale dan Henry George Keene, An Oriental Biographical Dictionary, (California: The University California Press, 1894), hal. 65. Bandingkan dengan William Bayne Fisher, The Cambridge History of Iran, (Cambridge: Cambridge University Press, 1968), hal. 132.

26 Ibn Katsir, al-Bidayah wa al-Nihayah, (Beirut: Dar al-Kutub al-'Ilmiyah, t.th.) juz 12, hal. 156. Informasi seperti ini bisa ditemui juga dalam karya Ameer Ali, A Short History of the Saracens (New Delhi: Kitab Bhavan, 1994), hal. 320.

27 Ibn Atsir, al-Kamil...hal. 231. Bandingkan dengan Ibn Katsir, al-Bidayah... hal. 156.

28 Ibn Katsir, al-Bidayah...hal. 156. Menurut al-Suyuthi, Ibn 'Aqil adalah seorang pakar bahasa yang memandikan jenazah al-Mustazhir yang meninggal pada tahun $512 \mathrm{H}$. Lihat Jalaluddin al-Suyuthi, Tarikh...hal. 338.

29 Ibn Atsir, al-Kamil...hal. 231. Dinasti Saljuk didirikan oleh orang-orang keturunan Turki yang pada masa kekuasaan Abbasiyah mendapat tempat penting di bidang politik, bahkan Saljuk menguasai secara de facto kekuasaan tersebut. Informasi tentang Dinasti Saljuk bisa dibaca karya Jurji Zaidan, Tarikh al-Tamaddun al-Islami, (Beirut: Dar Maktabah alHayah, 1967), Juz. 2, hal. 473. Karya lainnya, misalnya, Hassan Ibrahim Hassan, Islamic and History Culture from 632 to 1968, (Saudi Arabia: Kamal Adham, t.th), hal. 243267. 30 Ibn Katsir, al-Bidayah...hal. 156.

31 Informasi lebih lanjut mengenai hal ini baca karya Joesoef Sou'yb, seorang pengarang tanah air asal Sumatera Barat, Sejarah Daulat Abbasiyah III, Jakarta: Bulan Bintang, 1978), hal. 75.

32 Ameer Ali, A Short History...hal. 332.

33 Jalaluddin al-Suyuthi, Tarikh...hal. 335. Ibn Katsir, al-Bidayah...hal. 156157. Bandingkan dengan Abu al-Fida', al-Tibr al-Masbuk fi Tawarikh alMuluk, (Kairo: Maktabah al-Tsaqafat al-Diniyah, 1995), hal. 54.

34 Mustafa Abu Sway, al-Ghazali: A Study in Islamic Epistemology, (Kuala Lumpur: Dewan Bahasa dan Pustaka, 1996), hal. 2.

35 Jalaluddin al-Suyuthi, Tarikh...hal. 335. Untuk informasi lebih mendalam dengan ragam ilustrasi menarik, lihat G.E. Grunebaum, Classical Islam: A History 680-1258, (Chicago: Aldine Publishing Company, 1970), hal. 141-158. 
36 M. J. L. Young, Religion, Learning and Science in the Abbasid Period, (Cambridge: Cambridge University Press, 2006), hal. 443. Lihat juga M. A. Cook, Commanding Right and Forbidding Wrong in Islamic Thought, ((Cambridge: Cambridge University Press, 2000), hal. 124. Gerhard Endress dan Carole Hillenbrand, Islam: An Historical Introduction, (Edinburgh: Edinburgh University Press, 2002), hal. 172.

37 Menurut Bernard Lewis di Abad ke-13, kata Assassin, dengan aneka ragam bentuknya telah lazim digunakan di Eropa untuk menyebut kelompok pembunuh bayaran. Sejarawan kuno Fiorentina, Giovanni Villani, yang meninggal pada 1348, menggambarkan bagaimana Pangeran Lucca mengirim "assassin” ke Pisa untuk menghabisi seorang musuh yang merepotkannya. Dalam studi ini Assassin yang dimaksud akan dibahas kemduian. Dan informasi yang memadai mengenai kelompok ini dalam konteks kekuasaan Abbasiyah dan Saljuk bisa dibaca Bernard Lewis, The Assassins: A Radical Sect in Islam, (New York: Oxford University Press, 1987), hal. 1-37.

38 Joesoef Sou'yb, Sejarah Daulat...hal. 75. Bandingkan dengan Masudul Hasan, History of Islam, (Delhi: Adam Publishers and Distributors, 1995), hal. 284-285.

39 Abd al-Rahman Badawi, Madzahib al-Islamiyah, (Beirut: Dar al-'Ilm wa alMalayin, 1971), juz 2, hal. 313-323.

40 Zainal Abidin Ahmad, Konsepsi Negara Bermoral Menurut Imam al-Ghazali, (Jakarta: Bulan Bintang, 1976), hal. 276.

41 Jalaluddin al-Suyuthi, Tarikh...hal. 336.

42 Abd al-Rahman Badawi, Madzahib...hal. 313-323. Bandingkan dengan Bernard Lewis, The Assassins... hal. 64-96.

43 Lihat Farhad Daftary, "Ismaili Studies: Medieval Antecedents and Modern Deevelopment", The Institute of Ismail Studies, 2002, hal. 6-7. Lebih jauh mengenai karya dan pemikiran Farhad Daftary bisa dipelajari dalam karyanya yang lain, The Ismailis: Their History and Doctrin (Cambirdge: 1990); The Assassin Legends: Myths of the Ismailis (London: 1994); A Short History of Ismailis (Edinburgh: 1998); Medieval Ismaili History and Though (Cambrdge: 1996) dan; Intellectual Traditions in Islam (London: 2000).

44 Lebih jauh tentang masalah ini lihat artikel Farid Jabre, "la Biographie et l'oeuvre de Ghazali reconsiderees a la lumiere des Tabaqat de Sobki, MIDEO, 1, 1954. Karya lain Jabre, Essai sule lexique de Ghazali, (Beirut: Publications de L'Universite Libanaise, 1985). Termasuk karya Jabre, La notion de certitude selon ghazali: Dansses orgines sychologiques etm historiques, (Paris: Libraire Phiosophique, 1988).

45 Massimo Campanini, "Al-Ghazali"...., hal. 323.

46 Lihat artikel Carole Hillenbrand, "Islamic Orthodoxy or Realpolitik?; alGhazali's views on government", London, Iran; Journal of the British Institute of Persian Studies, 1988, hal. 82.

47 Carole Hillenbrand, "Islamic Orthodoxy or Realpolitik..., hal. 82.

48 Lihat Mustafa Abusway, Al-Ghazali: A Study in Islamic Epistemology, (Kualalumpur: Dewan Bahasa dan Pustaka, 1996), hal. 90-91.

49 Erwin E. J. Rosenthal, Political Thought in edieval Islam: An Introductory Outline, (Cambridge: Cambridge University Press, 1962), hal. 39.

50 Tetapi tampaknya argumen Corbin ini berbeda sama sekali dengan yang dikatakan oleh W Montgomery Watt, bahwa ketika hendak mengkritik aliran Bathiniyah, al-Ghazali 
terlebih dahulu mempelajari dengan saksama berbagai hal mengenai aliran itu. Lihat W Montgomery Watt, Muslim Intellectual: A Study of al-Ghazali,(Edinburgh:Edinburgh University Press, 1963), hal. 174-175.

51 Lihat al-Ghazali, Fadhaih ....hal. 169.

52 Al-Ghazali, Fadhaih ....hal. 169.

53 Al-Ghazali, Fadhaih ....hal. 184.

54 Al-Ghazali, Fadhaih ....hal. 176.

55 Al-Ghazali, Fadhaih ....hal. 176.

56 Mustafa Abusway, Al-Ghazali: A Study...., hal. 90.

57 Dikutip dari Massimo Campanini, “Al-Ghazali”...., hal. 324.

58 Dikutip dari Mahmud Hamdi Zaqzuq, al-Manhaj al-Falsafi Baina al-Ghazali wa Dikart, (Kairo: Dar al-Ma'arif, 1997), hal. 52-53.

59 Maksudnya, menurut al-Ghazali, dalam membuktikan kebenaran teori itu, mereka kadangkadang menerapkan pikiran yang logis, pada saat yang sama kaum Bathiniyyah mengingkari semua makna logika. Al-Ghazali menilai mereka adalah aliran sesat yang meniadakan dan mematahkan teori sendiri. Lihat al-Ghazali, Fadhaih al-Batiniyyah wa Fadhail al-Mustazhiriyyah, (Kairo: al-Dar al-Qaumiyah li al-Thaba'ah wa al-Nasyr, 1974), hal 53.

60 Dikutip dari Massimo Campanini, “Al-Ghazali”...., hal. 324. Bandingkan uraian serupa dengan Luke B Yarbrough, Knowledge of te Heart: Heart of Political Order al-Ghazali on Mysticism and Politics, Tesis pada Princeton University Departemen Sejarah, 2004, hal. 63.

61 Al-Ghazali melakukan kritik terhadap aliran Bathiniyyah setelah ia mempelajari dengan saksama aliran tersebut. Kritik al-Ghazali ini disampaikannya setelah ia mengkritik para mutakallimin dan kaum filosof pada masanya. Informasi lebih jauh tentang hal ini lihat 'Amir al-Najjar, Nadzarat fi Fikr al-Ghazali, (Ttt: Syirkah al-Shafaa, tth), hal. 112-113. 62 Massimo Campanini, “Al-Ghazali”...., hal. 323.

63 W. Montgomery Watt, Islamic Philosophy and Theology, (Edinburgh: Ediburgh University Press, 1985), hal. 14.

64 Kelompok Syi'ah memiliki keyakinan terhadapnya imam yang ma'sum. Mengenai hal ini sudah dijelaskan pada bagian sebelumnya, lihat Al-Ghazali, Fadhaih al-Bathiniyyah... hal. 79-131.

65 John L. Esposito, The Oxford History of Islam,... hal. 71.

66 Lihat Bernard Lewis, The Assassin..., hal. 67.

67 Secara literar berarti yang diberi petunjuk. Ia yang dipercaya yang akan mendudukkan segala kesalahan menjadi kebenaran dan akan menciptakan keadilan di muka bumi. Konsepsi mahdi ini adalah sesuai dengan pendapat Judaeo Kristen tentang al-Masih, kendati sebenarnya tidak identik. Lihat W. Montogomery Watt, Islamic Political Thought, (Edinburgh: Ediburgh University Press, 2003), hal. 44. Bandingkan juga karya lain Watt, yakni W. Montgomery Watt, Islamic Philosophy...hal. 17.

68 John L. Esposito, The Oxford History of Islam,... hal. 71.

69 Sebenarnya ada varian dari kelompok Syi'ah ini, yakni yang disebut Zaydiyah. Menurut mereka, imama tidak berlaku pada satu garis keturunan khusus. Meskipun demikian Zaydiyah menempatkan keturunan Ali sebagai orang yang dipandang sangat mampu 
untuk melaksanakan kepemimpinan efektif bagi generasinya. Lihat John L. Esposito, The Oxford History of Islam, hal. 72.

70 Bernard Lewis menginformasikan untuk studi lebih lanjut mengenai Ismailiyah buku karya A.S. Pickly, History of the Ismailis (Bombay: 1940) merupakan sumber yang sangat memadai. Buku ini dtulis oleh seorang penganut Ismailiyah untuk kalangan mereka sendiri. Karya dalam bahasa Arab mengenai subyek ini adalah karya seorang pengarang Ismailiyah asala Suriah, yakni Musthafa Ghalib, Tarikh al-Da'wa Ismailiyah (Damaskus: tanpa tahun terbit) dan karya menarik, berupa kamus, yakni A'lam Ismailiyah, 9Beirut: 1964). Karya penulis lepas (bukan pengikut Ismailiyah) yakni Muhammad Kamil Husain, diterbitkan di Kairo tahun 1959, yakni Ta'ifat al-Ismailiyah. Lihat Bernard Lewis, The Assassin..., hal. 144 .

71 Lihat Bernard Lewis, The Assassin..., hal. 78.

72 Dalam karya al-Ghazali, nama kelompok ini disebut-sebut sebagai nama lain aliran Ismailiyah atau Bathiniyah. Lihat al-Ghazali, Fadhaih al-Bathiniyyah... hal. 12.

73 John L. Esposito, The Oxford History of Islam, hal. 72.

74 Abd al-Rahman Badawi, Madzahib... hal. 313-323.

75 Zainal Abidin Ahmad, Konsepsi Negara Bermoral... hal. 276.

76 Jalaluddin al-Suyuthi, Tarikh...hal. 336.

77 Bernard Lewis menilai sasaran pembunuhan hanya ditujukan terhadap pemuka agama dan negara dari kalangan sunni. Lihat Lihat Bernard Lewis, TheAssassin..., hal. 134.

78 Farid Jabre, "la Biographie et l'oeuvre de Ghazali reconsiderees a la lumiere des Tabaqat de Sobki, MIDEO, 1, 1954. Karya lain Jabre, Essai sur le lexique de Ghazali, (Beirut: Publications de L’Universite Libanaise, 1985). Termasuk karya Jabre, La notion de certitude selon ghazali: Dans ses orgines psychologiques et historiques, (Paris: Libraire Phiosophique, 1988).

79 Carole Hillenbrand, "Islamic Orthodoxy or Realpolitik? al-Ghazali's views on government", London, Iran; Journal of the British Institute of Persian Studies, 1988, hal. 82.

80 Richard J. McCarthy, al-Mustazhari being a Translation of Fadaih al-Bathiniya wa Fadhail al-Mustazhiriyah of al-Ghazali with Translation and Annotation, (Twayne Publishers, 1980), hal. 175.

81 Farouk Mitha, al-Ghazali and the Ismailis...hal. 19.

82 Farouk Mitha, al-Ghazali and the Ismailis...hal. 19. Tentang pujian karya Farouk Mitha ini, lihat misalnya David B. Burrel, dosen Universitas Notre Dame USA, yang mengatakan bahwa studi Mitha mengusung sebuah metodologi yang canggih, baca review book karya Mitha oleh David B. Burrel, Journal of Philosophy: an International Journal for Comparative Philosophy and Mysticm, Vol. 3, 4, Desember 2002, hal. 404.

83 Lihat review book atas karya Farouk Mitha oleh Andrew Rippin, dosen sejarah pada Universitas Victoria, dalam Journal Studies in Religion, 31, 2, 2002, hal. 235.

84 Lihat review book atas karya Farouk Mitha oleh Frank Griffel, dosen pada Yale University, Journal of Semitic Studies, 48, 2003, hal. 406.

85 Frank Griffel, Review ... hal. 406.

86 Lihat kembali al-Ghazali, al-Munqidz ..., hal. 45.

87 Yusuf Qardhawi, al-Ghazali ..., hal. 99-100. 
88 Mengenai ha 1 ini telusuri karya Henri Corbin, "The Ismaili Response to the Polemic of al-Ghazali" in Ismaili Contribution to Islamic Culture, edited by S.H. Nasr, (Teheran: tp., 1977), ha. 67-98.

89 Tentang Hassan al-Sabah Bernard Lewis, The Assassin..., hal. 61-63.

90 Farouk Mitha, al-Ghazali and the Ismailis...hal. 19.

91 Bernard Lewis, The Assassin..., hal. 28.

92 Antony Black, The History of Islamic Political Thought, ... hal. 103-105.

93 Ketika Imam Fathimiyah, yaitu Khalifah al-Mustanshir wafat (1094), Hasan al-Sabah mendukung Nizar yang telah dipersiapkan oleh al-Mustanshir sebagai penggantinya. Tetapi tentara Fathimiyah menentangnya dan dianggap bertanggung jawab atas kematian Nizar. Uniknya, Hasan al-Sabah tiba-tiba mengaku sebagai hujah atau bukti keberadaan Imam Nizar sampai tiba saatnya Nizar memutuskan untuk muncul kembali ke dunia. Selanjutnya, Hasan alSabah dan para pendukungnya memproklamirkan sebuah versi baru dari gerakan politik keagamaan Ismailiyah yang mereka sebut sebagai al-da'wah al-jadidah. Antony Black ... hal. 104.

94 Henry Corbin, "the Ismaili Response...", 79.

95 Frank Griffel, Review ..., hal. 404.

96 Henry Corbin, "the Ismaili Response...", 79.

97 Richard J. McCarthy, al-Mustazhiry...,hal. 182.

98 Luke B. Yarbrough, Knowledge of the Heart...hal. 48.

99 Luke B. Yarbrough, Knowledge of the Heart...hal. 48. Menurut al-Ghazali Eksistensi alMustazhir sebagai pemimpin sudah sesuai dengan syari'ah. Oleh sebab itu, pagi para mufti dan juga para ulama wajib memberikan informasi tentang hal ini kepada seluruh rakyat untuk mentaatinya. Karena, semua kualifikasi yang dimilikinya sudah sesuai hukum, termasuk pengangkatan dan pelantikan dirinya dan para pembesar lainnya. Semuanya sah. Dan alMustazhir dapat mempergunakan semua hak yang telah diberikan oleh Tuhan tersebut (untuk memerintah). Al-Ghazali, Fadhaih al-Bathiniyyah...,hal. 181-182.

100 Al-Ghazali, Fadhaih al-Bathiniyyah..., hal. 181.

101 Al-Ghazali, Fadhaih al-Bathiniyyah... hal. 182-191.

102 Luke B. Yarbrough, Knowledge of the Heart...hal. 52. 